\title{
A rare type of burn injury due to butane gas inhalation
}

\author{
Ergin Seven, M.D., ${ }^{1}$ Uğur Horoz, M.D., ${ }^{1}$ Elif Sarı, M.D., ${ }^{2}$ Hülda Rifat Özakpınar, M.D.,, \\ Mert Muhittin Sandıkcı, M.D., ${ }^{1}$ Emre İnözü, M.D., ${ }^{1}$ Ali Teoman Tellioğlu, M.D. ${ }^{3}$
}

\begin{abstract}
1'Department of Plastic, Reconstructive and Aesthetic Surgery, Dışkapı Yıldırım Beyazıt Training and Research Hospital; Ankara-Turkey ${ }^{2}$ Department of Plastic, Reconstructive and Aesthetic Surgery, Kırıkkale University Faculty of Medicine; Kırıkkale-Turkey ${ }^{3}$ Department of Plastic, Reconstructive and Aesthetic Surgery, Yıldırım Beyazıt University Faculty of Medicine; Ankara-Turkey
\end{abstract}

\begin{abstract}
BACKGROUND: Abusive inhalation of butane gas is becoming a serious public health problem among teenagers and young adult population; however, there has been little reporting on explosion burns associated with abuse of butane cigarette lighter fluid.

METHODS: Retrospective study was conducted of 22 patients who were burned in last 2 years in explosion of butane gas, a flammable, odorless, and colorless aliphatic hydrocarbon.

RESULTS: Details of sociodemographic profile of the patients, any underlying psychiatric illness, alcohol abuse, depth of burn injury, any associated injury, duration of hospitalization, and percentage of burned area were recorded and analyzed.
\end{abstract}

CONCLUSION: All of the patients were young men, and most had superficial burn injury. Hospital stay ranged from 0 to II days. All of the patients were treated with conservative management.

Keywords: Abuse; burn; butane; explosion.

\section{INTRODUCTION}

Burn is individual and highly variable injury that can occur in all ages and social groups. Types of burn injury include thermal, chemical, or electrical burn. ${ }^{[1]}$ Flash or explosion burns are most often seen in industrial injuries, and typically result from ignition of flammable gas. Explosion injuries caused by terrorist attacks or received in combat have been widely described, but there is little in the literature related to gas explosion burns related to inhalant abuse. ${ }^{[2-4]}$ Explosion injuries, a type of flash injury, can be classified into 4 types. Type I is primary blast injury (blast wave), type 2 is secondary blast injury (ballistic trauma), type 3 is tertiary blast injury (caused by a combination of blunt and penetrating traumas), and type 4 is quaternary blast injury (burns and other injuries not in previous categories). ${ }^{[2]}$

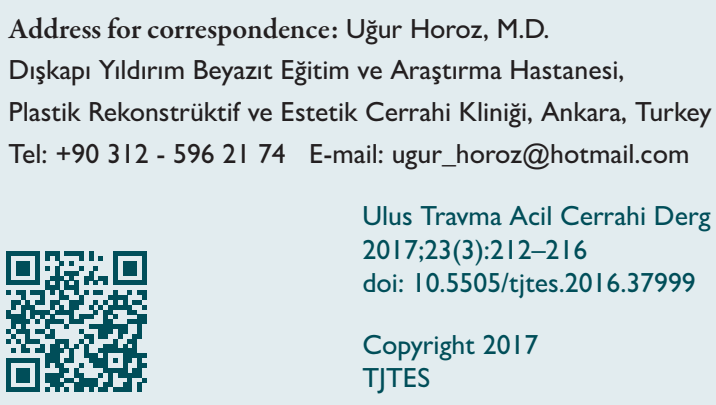

Butane, an aliphatic hydrocarbon derived from petroleum, is highly flammable, odorless, colorless, nonhalogenated gas. Butane gas is used as fuel for cooking and heating, lighter fluid, refrigerant, deodorant propellant, and for industrial purposes, among other applications. ${ }^{[3-10]}$ Boiling point of butane gas is $-0.5^{\circ} \mathrm{C} \cdot{ }^{[4,8,10]}$ As it has many uses in daily life, butane gas is widely available in stores without any legal restriction. ${ }^{[3-1 I]}$ Inhalant abuse is becoming an important public health problem. ${ }^{[6,7,11]}$ When butane gas inhalant enters pulmonary system it displaces oxygen from red blood cells. ${ }^{[3-19]}$ Butane gas is absorbed by various tissues and has elective tropism for the encephalon, spleen, liver, and kidneys. ${ }^{[6]}$ Reactions begin within 5 minutes and acute period typically lasts between 15 and 45 minutes. ${ }^{[4]}$ Butane gas inhalation may cause euphoria, dizziness, and hallucinations after inhalation. ${ }^{[3-7]}$ Effect depends on the duration of inhalation, quantity of substance inhaled, and its concentration. It causes toxicity to several organ systems, depending on exposure time and concentration of the gas. ${ }^{[3-6]}$ Acute and short-term side effects of butane inhalation, including sudden death, as well effects of chronic exposure are provided in Table I and Table $2 .^{[3-7,9-19]}$

Burns reported related to butane gas were usually due to explosion of camping gas, accident during motor vehicle refueling, or abusive inhalation of the gas. ${ }^{[2-4,9-17]}$ The present study 
Table I. Side effects of butane gas inhalation

\begin{tabular}{ll}
\hline Exposure type & Signs, symptoms and effects \\
\hline Acute & Irritability, cough, euphoria, excitation, nausea, headache, rhinorrhea, sneezing, vomiting, syncope \\
Alert symptoms & Abnormal speech, headache, confusion, delusions, decreased reflex. \\
Shortly after & Anoxia, tachycardia, hallucinations of all senses, ataxia, dissociation, hypoxia, tinnitus, nystagmus, dizziness \\
Chronic & Neurological, psychiatric, hematological, renal, pulmonary, cardiovascular \\
Sudden & Fatal arrhythmia, asphyxia, hypoxia, central nervous system depression, cardiac arrest, asystole, ventricular \\
& fibrillation, sudden death \\
\hline
\end{tabular}

Table 2. Chronic effects of butane gas on multiple organ systems

\begin{tabular}{ll}
\hline System & Chronic effects \\
\hline Renal & Hematuria, proteinuria, renal tubular acidosis, acid-base disturbance, renal failure \\
Cardiovascular & Dysrhythmias, myocardial fibrosis, direct myocardial toxicity, myopericarditis \\
Neurological & Ataxia, optic atrophy, sensorineural hearing loss, dementia, peripheral neuropathy, tremor, loss of motor control \\
Psychiatric & Depression, insomnia, memory loss, psychosis \\
Hematological & Anemia, thrombocytopenia, leukopenia \\
Pulmonary & Cough, emphysema, chemical pneumonitis \\
\hline
\end{tabular}

is review of 22 patients with rare type of burn injury resulting from butane gas inhalation abuse and explosion.

In an enclosed space, vapor becomes extremely flammable and explosive when ignition source is introduced, whether it be flame or spark. ${ }^{[3,4,16]}$ Emergency staff need to be aware of special circumstances in these scenarios and remove inhaling victim's clothing (decontamination), as well as follow pulse, oxygen saturation, and cardiac activity closely. These initial management steps should precede approach used for typical burn patient.

Records of 22 patients who were admitted our burn unit over 2 years were reviewed. All of the injuries occurred as result of butane gas explosion in enclosed car when cigarette lighter was ignited. Face and upper extremities were most affected areas. All of the injuries were treated conservatively. The aim of this study is to report an unusual burn type due to gas explosion after inhalant misuse, as well as examine incidence and detrimental effects of a different type of substance abuse.

\section{MATERIALS AND METHODS}

The study was conducted over a period of 2 years (20132014). Records of 22 patients who were treated for effects of explosion that occurred when inhaling butane gas were reviewed. All of the injuries took place inside vehicle. Butane gas was discharged into car by group of young men in order to inhale it, and explosion occurred when cigarette lighter was ignited in presence of flammable gas. All burn injuries were localized on upper extremities or face (Figure la-e). All patients were male, single, and smokers. All 22 patients had history of alcohol use at varying rates. There had been no previous diagnosis of any psychiatric disorder. Groups of 2 to 4 men were involved in total of 6 explosions. Age of patients in present study ranged between 17 and 24 years (median: 19.1 years). Average extent of injury was $8.5 \%$ of total body surface area (range: 3-20\%), and were usually second-degree superficial burns.

\section{RESULTS}

Clinical findings did not note any direct consequence of butane gas inhalation, such as euphoria, impaired coordination, disorientation, behavioral changes, or confusion. There were no electrocardiographic changes observed, or inhalation injuries due to explosion of the gas. Hospital stay ranged from

Table 3. Butane gas explosion burn patients $(n=22)$

\begin{tabular}{ll}
\hline Male to female ratio & $22-0$ \\
Age range (average) & $17-24$ (19.I) years \\
Extent of injury (total body area) & $3-20 \%$ \\
Length of hospital stay & $0-11$ days \\
Discharged on same day & 4 \\
Number who consume alcohol & 22 \\
Number discharged to home & $100 \%$ \\
Number with inhalation injury & 0 \\
\hline
\end{tabular}



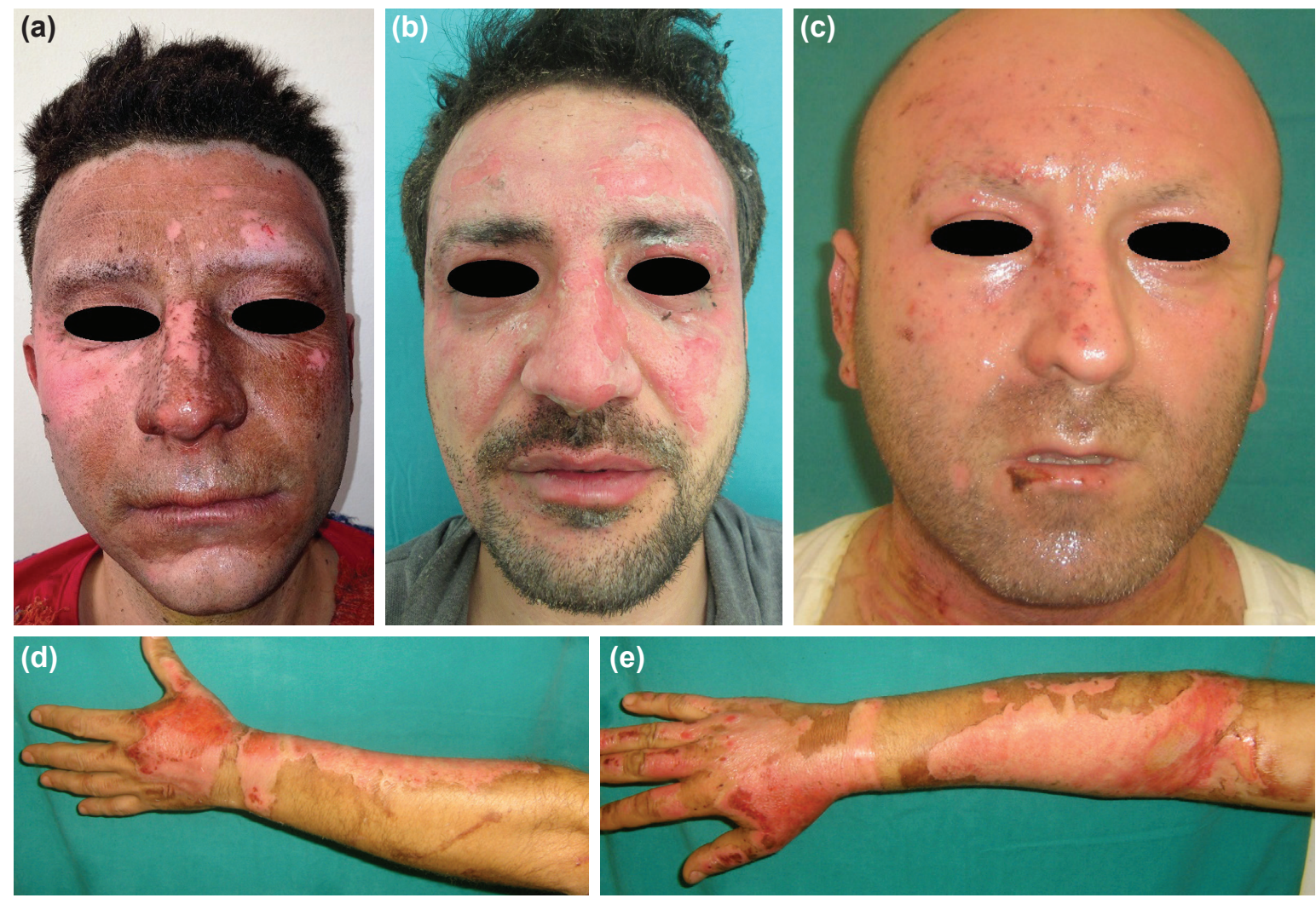

Figure 1. (a) A 19-year-old patient with facial burn treated conservatively. (b) A 21 -year-old patient whose facial burn improved under conservative management without hospitalization. (c) A 22-year-old patient whose hand and facial burns improved under conservative management. (d) Left hand of a 22-year-old burn patient. (e) Right hand of a 22-year-old patient.

0 to II days, with mean of 3.5 days. All wounds healed with dressing and antibacterial ointment; none required surgical intervention. No complications or repetition of patient injury were observed. The primary aim of this study was to demonstrate different type of substance abuse using combustible butane gas and potential results. Patient details are summarized in Table 3.

\section{DISCUSSION}

Inhalant misuse has become more popular among adolescents and young adults in the last few decades. ${ }^{[6]}$ Butane is found in many common items, such as cleaning products, paint, shoe polish, gasoline, glue, aerosol propellant, bug bombs, lighter fluid, and sealants..$^{[3-5,11-16]}$ Inhalants can be found in offices and homes, and are easily and inexpensively purchased in stores, as they are not legally controlled substances. ${ }^{[3-16]}$ Three of the methods of inhalant abuse that have been reported are "Sniffing," direct inhalation from the source; "bagging," pouring the substance into a bag and breathing from the bag while it is held over the mouth and nose; and "huffing," inhalation of vapors from piece of cloth that has been soaked with inhalant. $[5,6]$ Sequentially, abusers typically adopt sniffing, huffing, and finally bagging in order to get greater concentration of inhalant and prolong the effects. ${ }^{[6,18]}$ Direct inhalation from source or using plastic bag provides more concentrated exposure in short period of time. Once inhaled, hypotension and tachy- cardia develop, followed by increase in cardiac output and bradycardia. ${ }^{[6]}$ Butane gas affects multiple organs, such as central nervous system (CNS), myocardium, liver, spleen, and kidneys. Gas leaves the body via exhalation.

Butane and isobutane are primary volatile components of cigarette lighter fuel and other products, and they have an anesthetic, sedative, narcotic effect on CNS. ${ }^{[8-10]}$ Chronic butane abuse may lead to selective thalamic damage in the brain. It can also increase dopamine level and prompt fatal arrhythmia Sudden death has been associated with acute inhalation of gas. Butane sensitizes cardiac muscles to effects of catecholamines, predisposing patient to epinephrine-induced cardiac arrhythmia. ${ }^{[8,10]}$ After breathing the gas in an enclosed area, acute effects begin within 5 minutes. Kurtzman et al. pointed out that effects occur and disappear more quickly when compared with other drugs. Abusers can return to daily activities without any significant symptoms. ${ }^{[6]}$ Abusers typically begin to increase the frequency and duration of inhalants when they want to extend the effects. Inhalant misuse is increasing because abusers can find the items easily, they are low-cost, and they are legal. Inhalant abuse has been reported among small groups in young population. ${ }^{[6]}$ It has also been reported that abusers have higher rate of suicide attempt compared with contemporaries. ${ }^{[1,13,19]}$ Freedenthal et al. and Rossi et al. reported between $9 \%$ and $20 \%$ of adolescents had mis- 
used inhalants, and that girls had more psychopathological and behavioral problems in the juvenile population. ${ }^{[19]}$ Wick et al. found 39 deaths related to gasoline and butane inhalation in retrospective study of 18880 autopsies. ${ }^{[7]}$ Inhalants are easily absorbed by lipid-rich tissues and CNS is vulnerable to toxic effects. ${ }^{[6]}$ Toluene is a toxic aromatic hydrocarbon that primarily affects $\mathrm{CNS} .{ }^{[6]}$ Spontaneous abortion and premature parity risks increase when inhalants are used during pregnancy. ${ }^{[5,6]}$ It has also been reported that inhalation abusers usually have problems with family, friends, or academics, and may have suicidal thoughts. ${ }^{[6,13,19]}$ Busche et al. reported on $7 \mathrm{I}$ patients burned in gas explosions; total of II were injured during recreational activities and 4 burn cases were smoking-related (gas lighters). More than half of burn injuries occurred in private households. ${ }^{[2]}$

Explosion burns that occurred during inhalation of butane abuse gas have been reported in the literature. ${ }^{[3,4]}$ In 1992, Scerri et al. described 7 patients who were burned in explosion after gathering as a group in an enclosed car to inhale butane gas. All patients were treated with conservative management. ${ }^{[3]}$ In 1999, Oh et al. reported explosion burns in 48 patients who had inhaled butane gas at home or in motel rooms. ${ }^{[4]}$ In 5-year retrospective study, 5 patients died during hospitalization, 22 patients needed skin graft, 12 patients were followed with conservative management, and 9 were treated and discharged or transferred. Rates of mortality and severe injuries were likely related to limited space of enclosed area and amount of gas. Marc et al. ${ }^{[16]}$ reported fatal case of woman who used air freshener in the kitchen and died in subsequent flash fire. Sugie et al. ${ }^{[10]}$ reported 3 cases of sudden death due to butane or propane gas inhalation. Seyhan et al. ${ }^{[15]}$ and Wright et al. ${ }^{[17]}$ also reported liquefied petroleum gas (butane and isobutene are primary ingredients)-related cold injuries.

Inhalant abuse is becoming a serious public health problem which has been underreported and poorly reviewed. ${ }^{[6]}$ Burns related to gas explosions need special attention as result of thermal trauma as well as possible associated psychopathological problems of abusers. Psychological evaluations and required support should be provided in cases of inhalant abuse.

\section{Conclusion}

Studies targeting abusers and their friends at an early age should be conducted to prevent and discourage misuse of inhalants. Studies should not only try to make teenagers aware of health threats in abuse of inhalants, but must also highlight public health problem. We physicians should be worried about misuse of inhalants by young population, a problem that is growing and still too much of a mystery. To the best of our knowledge this is the second report in the literature regarding explosions in enclosed cars due to butane and the third report of the explosion burns received during inhalation of butane gas.

\section{Conflict of interest: None declared.}

\section{REFERENCES}

1. Thorne CH, Chung KC, Gosain AK. Grabb and Smith's Plastic Surgery. 7th ed: Philadelphia: Lippincott Williams \& Wilkins: 2014.

2. Busche MN, Gohritz A, Seifert S, Herold C, Ipaktchi R, Knobloch K, et al. Trauma mechanisms, patterns of injury, and outcomes in a retrospective study of 71 burns from civil gas explosions. J Trauma 2010;69:92833. [CrossRef]

3. Scerri GV, Regan PJ, Ratcliffe RJ, Roberts AH. Burns following cigarette lighter fluid abuse. Burns 1992;18:329-31. [CrossRef]

4. Oh SJ, Lee SE, Burm JS, Chung CH, Lee JW, Chang YC, et al. Explosive burns during abusive inhalation of butane gas. Burns 1999;25:341-4.

5. Anderson CE, Loomis GA. Recognition and prevention of inhalant abuse. Am Fam Physician 2003;68:869-74.

6. Kurtzman TL, Otsuka KN, Wahl RA. Inhalant abuse by adolescents. J Adolesc Health 2001;28:170-80. [CrossRef]

7. Wick R, Gilbert JD, Felgate P, Byard RW. Inhalant deaths in South Australia: a 20-year retrospective autopsy study. Am J Forensic Med Pathol 2007;28:319-22. [CrossRef]

8. Fuke C, Miyazaki T, Arao T, Morinaga Y, Takaesu H, Takeda T, et al. A fatal case considered to be due to cardiac arrhythmia associated with butane inhalation. Leg Med (Tokyo) 2002;4:134-8. [CrossRef]

9. Bayar N, Baş CY, Erkal Z, Arslan Ş. A case of myopericarditis following butane gas inhalation. [Article in Turkish] Anadolu Kardiyol Derg 2013;13:505-6. [CrossRef]

10. Sugie H, Sasaki C, Hashimoto C, Takeshita H, Nagai T, Nakamura S, et al. Three cases of sudden death due to butane or propane gas inhalation: analysis of tissues for gas components. Forensic Sci Int 2004;143:211-4.

11. Akcan R, Cekin N, Hilal A, Arslan MM. Sudden death due to inhalant abuse in youth:Case Report. Dicle Medical Journal 2010;37:154-6.

12. Khalessi A, Maitz P, Haertsch P, Kennedy P. Adult burn injuries due to domestic barbeques in New South Wales. Burns 2008;34:1002-5. [CrossRef]

13. Rossi R, Suadoni F, Pieroni L, De-Giorgio F, Lancia M. Two cases of acute propane/butane poisoning in prison. J Forensic Sci 2012;57:8324. [CrossRef]

14. Farace F, Gallo A, Lissia M, Di Giulio S, Mele A, Rubino C. Camping gas burns: our experience. J Plast Reconstr Aesthet Surg 2007;60:450-1.

15. Seyhan N, Jasharllari L, Kayapınar M, Savacı N. An unusual cause of cold injury: liquified petroleum gas leakage. Ulus Travma Acil Cerrahi Derg 2011;17:561-2. [CrossRef]

16. Marc B, Blanchet P, Boniol L. Domestic aerosol and flash fire: warning from a fatal case. Burns 2001;27:783-4. [CrossRef]

17. Wright TC, Kim JB, Currie LJ, Kay AR, Burge TS. Leakage of liquefied petroleum gas during motor vehicle refuelling--a new cause of cold injury. Burns 2006;32:132-3. [CrossRef]

18. Desouches C, Salazard B, Romain F, Karra C, Lavie A, Volpe CD, et al. Analysis of burns caused by pre-filled gas canisters used for lamps or portable camping stoves. Burns 2006;32:1028-31. [CrossRef]

19. Freedenthal S, Vaughn MG, Jenson JM, Howard MO. Inhalant use and suicidality among incarcerated youth. Drug Alcohol Depend 2007;90:81-8. [CrossRef] 


\section{ORİINAL ÇALIŞMA - ÖZET}

\section{Bütan gazının inhalasyon yoluyla kötüye kullanımına bağlı nadir görülen yanıklar}

Dr. Ergin Seven, ${ }^{1}$ Dr. Uğur Horoz, ${ }^{1}$ Dr. Elif Sarı, ${ }^{2}$ Dr. Hülda Rıfat Özakpınar, ${ }^{1}$

Dr. Mert Muhittin Sandıkcı, ${ }^{1}$ Dr. Emre İnözü, ${ }^{1}$ Dr. Ali Teoman Tellioğlu ${ }^{3}$

${ }^{1}$ Dışkapı Yıldırım Beyazıt Eğitim ve Araştırma Hastanesi, Plastik, Rekonstruktif ve Estetik Cerrahi Kliniği, Ankara

${ }^{2}$ Kırıkkale Üniversitesi Tıp Fakültesi, Plastik, Rekonstruktif ve Estetik Cerrahi Anabilimdalı, Kırıkkale

${ }^{3}$ Yıldırım Beyazıt Üniversitesi Tıp Fakültesi, Plastik, Rekonstruktif ve Estetik Cerrahi Anabilimdalı, Ankara

AMAÇ: İnhalasyon yoluyla bütan gazı kötüye kullanımı ergen ve genç erişkinlerde giderek artan halk sağlığı problemi halini almaktadır. Çakmak gazı olarak kullanılan bütan gazının suistimali sırasında oluşan patlama yanıkları az sayıda bildirilmiştir.

GEREÇ VE YÖNTEM: Son iki yılda, kokusuz ve renksiz bir gaz olan bütan gazının alev alması sonucu oluşan parlamalarla yaralanmış 22 hastayı içeren geriye dönük bir çalışma gerçekleştirildi.

BULGULAR: Hastaların sosyo-demografik özellikleri, mevcut psikiyatrik hastalıkları, alkol bağımlıı̆ı̆, yanığın derinliği, eşlik eden yaralanmalar, hastanede kalıs süreleri ve yanık yüzdesi kayıt edildi.

TARTIŞMA: Hastaların tamamı erkek ve çoğunun yanıkları yüzeyel olarak görüldü. Hastaların hastanede kalıs süreleri 0-II gün arasında değişmekteydi. Hastaların tamamı konservatif yöntemlerle tedavi edildi.

Anahtar sözcükler: Butan; suistimal; patlama; yanık.

Ulus Travma Acil Cerrahi Derg 2017;23(3):212-216 doi: 10.5505/tjtes.2016.37999 